\title{
PENGEMBANGAN MEDIA PEMBELAJARAN BERUPA BULETIN DALAM BENTUK BUKU SAKU UNTUK PEMBELAJARAN IPA TERPADU
}

\author{
Ardian Asyhari ${ }^{1}$, Helda Silvia ${ }^{2}$ \\ 1,2IAIN Raden Intan Lampung, Bandarlampung; e-mail: ardianasyhari@ radenintan.ac.id \\ Diterima: 21 Desember 2015. Disetujui: 5 April 2016. Dipublikasikan: April 2016
}

\begin{abstract}
This research aims to; 1) develop learning media in the form of an integrated science bulletin on sound material; 2) investigate the response of students to the feasibility study media in the form of an integrated science bulletin on sound material for students of class VIII, with the formulation of the problem; 1) How to develop learning media in the form of an integrated science bulletin on sound material ?; 2) How is the response of students to the feasibility study media in the form of an integrated science bulletin on sound material. This study is a $R \& D$ method which adopting development of Borg \& Gall. Subjects in this study were students of class VIII SMP Negeri 7 Bandar Lampung and SMPN 21 Bandar Lampung amounted to 40 learners and data collection instruments used in the form of a questionnaire given to subject matter experts, media experts, and a science teacher SMP to test the feasibility of media learning in a bulletin in the form of a pocket book for integrated science teaching. The type of data that is generated is a qualitative and quantitative data were analyzed with the guidelines criteria to determine eligibility assessment category product. The results of this study are; 1) has developed learning media in the form of an integrated science bulletin in the form of a pocket book; 2) feasibility study media bulletin integrated science that has been developed is very feasible with a percentage of $82 \%$ is based on an expert assessment materials after the final stage of repair, design expert with a percentage of $79.4 \%$ with the criteria of decent; 3) the percentage was $77.6 \%$, a teacher the criterion is a decent; 4) the results of the response of learners with a percentage of $80 \%$ with the criteria are eligible.
\end{abstract}

\begin{abstract}
Abstrak: Penelitian ini bertujuan untuk; 1) mengembangkan media pembelajaran berupa buletin IPA terpadu dalam bentuk buku saku pada materi bunyi; 2) mengetahui respon peserta didik terhadap kelayakan media pembelajaran berupa buletin IPA terpadu pada materi bunyi dalam bentuk buku saku untuk peserta didik kelas VIII, dengan rumusan masalah; 1) Bagaimana mengembangkan media pembelajaran berupa buletin IPA terpadu dalam bentuk buku saku pada materi bunyi?; 2) Bagaimana respon peserta didik terhadap kelayakan media pembelajaran berupa buletin IPA terpadu dalam bentuk buku saku pada materi bunyi. Penelitian ini merupakan penelitian R\&D yang mengadopsi pengembangan dari Borg \& Gall. Subjek dalam penelitian ini adalah peserta didik kelas VIII SMP Negeri 7 Bandar lampung dan SMP Negeri 21 Bandar Lampung berjumlah 40 orang peserta didik dan instrumen pengumpulan data yang digunakan berupa angket yang diberikan kepada ahli materi, ahli media, dan guru IPA SMP untuk menguji kelayakan media pembelajaran berupa buletin dalam bentuk buku saku untuk pembelajaran IPA terpadu. Jenis data yang dihasilkan adalah data kualitatif dan kuantitatif yang dianalisis dengan pedoman kriteria kategori penilaian untuk menentukan kelayakan produk. Hasil penelitian ini adalah; 1) telah dikembangkan media pembelajaran berupa buletin IPA terpadu dalam bentuk buku saku; 2) kelayakan media pembelajaran buletin IPA terpadu dalam bentuk buku saku yang telah dikembangkan adalah sangat layak dengan persentase $82 \%$ berdasarkan penilaian ahli materi tahap akhir setelah perbaikan, ahli desain dengan persentase $79,4 \%$ dengan kriteria layak 3 ) dengan persentase adalah $77,6 \%$, penilaian guru dengan kriteria adalah layak 4) hasil respon peserta didik dengan persentase $80 \%$ dengan kriteria layak.
\end{abstract}

(C) 2016 Pendidikan Fisika FTK IAIN Raden Intan Lampung

Kata kunci: buku saku, buletin, media pembelajaran

\section{PENDAHULUAN}

Sesuai dengan amanat Kurikulum Tingkat Satuan Pendidikan (KTSP), bahwa model pembelajaran terpadu merupakan salah satu model implementasi kurikulum yang dianjurkan untuk diaplikasikan pada semua jenjang pendidikan, diaplikasikan terutama pada jenjang pendidikan dasar mulai dari Sekolah Dasar/Madrasah Ibtidaiah 
(SD/MI) maupun juga Sekolah Menengah Pertama (SMP/MTs) tetapi juga tidak menutup kemungkinan untuk dikembangkan pada tingkat pendidikan menengah, baik Pendidikan Menengah Umum (SMA/MA) maupun pendidikan Menengah Kejuruan (SMK/MAK). Hal ini bergantung pada kecenderungan materi-materi yang memiliki potensi untuk dipadukan dalam suatu tema tertentu. Model pembelajaran ini pada hakikatnya merupakan suatu pendekatan pembelajaran yang memungkinkan peserta didik baik secara individual maupun kelompok aktif mencari, menggali, dan menemukan konsep serta prinsip secara holistis dan autentik (Trianto, 2012).

Trianto (2012) melanjutkan bahwa pembelajaran terpadu, suatu konsep atau tema dibahas dari berbagai aspek bidang kajian. Misalnya dalam bidang kajian IPA tentang tema lingkungan dapat dibahas dari sudut makhluk hidup dan proses kehidupan (biologi), energi dan perubahannya (fisika), materi dan sifatnya (kimia).

Berdasarkan penjabaran di atas maka, guru dituntut untuk berperan aktif dalam proses belajar di dalam kelas, sehingga guru harus mampu memberikan pembelajaran yang efektif, kreatif dan inovatif. Peserta didik juga harus aktif dalam proses pembelajaran karena pada (KTSP) pelajaran dibuat secara terpadu antara pelajaran yang satu dengan yang lainnya, misalnya pada pelajaran IPA antara penggabungan fisika, biologi, dan kimia. Guru harus mampu menggunakan suatu media pembelajaran agar peserta didik lebih mudah memahami materi yang guru sampaikan.

Pendidikan yang efektif adalah suatu pendidikan yang memungkinkan peserta didik untuk dapat belajar dengan mudah, menyenangkan dan dapat tercapai tujuan sesuai dengan yang diharapkan. Dengan demikian, pendidik (dosen, guru, instruktur, dan trainer) dituntut untuk dapat meningkatkan keefektifan pembelajaran agar pembelajaran tersebut dapat berguna bagi peserta didik.

Berdasarkan pada pra-penelitian menggunakan angket wawancara dengan guru bidang studi yang dilakukan di SMP Negeri 7 Bandar Lampung, bahwa pada pembelajaran IPA guru lebih sering menggunakan lembar kegiatan siswa (LKS) dan buku cetak berukuran besar dalam proses pembelajaran, belum adanya media pembelajaran buletin dalam bentuk buku saku yang digunakan guru pada pembelajaran IPA, kurangnya minat baca peserta didik terhadap buku cetak karena memiliki uraian baca yang panjang. Media pembelajaran yang akan dikembangkan yang dapat mendukung proses pembelajaran IPA terpadu di SMP/MTs adalah berupa buletin dalam bentuk buku saku.

Menurut Setyono (2013) dalam penelitiannya menunjukkan bahwa media pembelajaran yang dikembangkan berupa buletin fisika dalam bentuk buku saku memiliki kriteria sangat baik berdasarkan penilaian dari ahli materi, ahli Bahasa Indonesia, dan ahli media memberikan rata-rata penilaian sebesar $86,56 \%$.

Selanjutnya sebagai media pembelajaran buletin IPA terpadu dapat memberikan nuansa belajar yang menarik. Pembelajaran IPA dengan buletin dapat dilakukan di dalam maupun di luar kelas. Belajar yang demikian dapat memberikan kesenangan tersendiri untuk peserta didik, sehingga materi yang sebenarnya sulit menjadi mudah bagi peserta didik. Menanggapi hal ini, diperlukan media pembelajaran alternatif yang dapat menarik minat mereka dalam membaca dan mempelajari materi dalam IPA terpadu.

Peran buku sangat besar karena buku dapat berperan sebagai sumber informasi, tetapi saat ini peserta didik juga memiliki kecenderungan kurangnya minat untuk membaca jika buku itu tebal dan kurang menarik. Perlu adanya usaha 
untuk menjadikan buku sebagai suatu yang menarik, sehingga akan memberi kesenangan kepada peserta didik untuk tertarik melihat buku dan membacanya seperti buletin IPA terpadu yang akan dikembangkan.

Pemakaian buletin IPA terpadu sebagai media pembelajaran, diharapkan peserta didik lebih mudah dalam memahami materi pembelajaran karena materi dalam buletin dalam bentuk buku saku ini disusun ringkas dan mudah dipahami peserta didik serta dibuat menarik agar peserta didik termotivasi untuk membaca dan mempelajarinya.

Tujuan dari penelitian ini adalah untuk mengembangkan media pembelajaran berupa buletin IPA terpadu pada materi bunyi dan untuk mengetahui respon peserta didik terhadap kelayakan media pembelajaran berupa buletin IPA terpadu pada materi bunyi

\section{LANDASAN TEORI}

\section{Media Pembelajaran}

Sumiati (2008) menjelaskan bahwa media pembelajaran merupakan bagian integral dalam sistem pembelajaran. Banyak macam media pembelajaran dapat digunakan. Penggunaannya meliputi manfaat yang banyak pula. Penggunaan media pembelajaran harus didasarkan pada pemilihan yang tepat. Sehingga dapat memperbesar arti dan fungsi dalam menunjang efektivitas dan efisiensi proses pembelajaran.

Media pembelajaran juga dapat diartikan sebagai segala sesuatu yang dapat digunakan untuk menyalurkan pesan (message), merangsang pikiran, perasaan, perhatian, dan kemauan peserta didik sehingga dapat mendorong proses belajar. Bentuk-bentuk media pembelajaran digunakan untuk meningkatkan pengalaman belajar agar menjadi konkret. Pembelajaran dengan menggunakan media pembelajaran tidak hanya sekedar menggunakan kata-kata (symbol verbal). Dengan demikian, dapat kita harapkan hasil pengalaman belajar lebih berarti bagi peserta didik. Dalam hal ini Gagne dan Briggs menekankan pentingnya media pembelajaran sebagai alat untuk merangsang proses belajar.

Berdasarkan definisi tentang media pembelajaran di atas dapat disimpulkan bahwa media pembelajaran adalah suatu alat atau benda yang dapat digunakan untuk perantara menyalurkan isi pelajaran atau materi yang disampaikan agar peserta didik mudah untuk memahami materi yang disampaikan oleh guru.

\section{Jenis-jenis Media Pembelajaran}

Berdasarkan penggunaan atau pemakai yang memanfaatkan media pembelajaran, jenis media pembelajaran terdiri atas (Sumiati, 2008):

a. Media pembelajaran yang digunakan untuk pembelajaran secara massal atau banyak orang. Contoh: belajar melalui televisi atau radio.

b. Media pembelajaran yang digunakan untuk pembelajaran secara individual atau perorangan. Contoh: belajar melalui modul atau buku.

Berdasarkan jenis-jenis media pembelajaran yang telah dikemukakan di atas dapat disimpulkan bahwa jenis media berdasarkan penggunaan atau pemakaian yang memanfaatkan media pembelajaran yakni media pembelajaran yang digunakan ada 2 yakni secara massal dan individual. Pembelajaran secara massal contohnya belajar melalui televisi, radio, dan internet, sedangkan pembelajaran secara individual bisa melalui modul, buku, dan buletin.

\section{Manfaat Media Pembelajaran}

Penggunaan media pembelajaran oleh guru dalam pembelajaran tidak mutlak harus diadakan. Namun akan lebih baik jika digunakan media pembelajaran karena media pembelajaran tentu mempunyai kelebihan-kelebihan yang dapat dimanfaatkan untuk membantu keberhasilan pembelajaran. Manfaat atau kelebihan media pembelajaran antara lain: 
a. Menjelaskan materi pembelajaran atau obyek yang abstrak (tidak nyata) menjadi konkret (nyata), seperti menjelaskan rangka tubuh manusia pada mata pelajaran IPA. Tulang rangka tubuh pada setiap manusia tentu ada namun tidak dapat dilihat langsung secara kasat mata karena tertutup oleh kulit. Dengan menggunakan media pembelajaran tulang rangka atau gambar tulang rangka, maka materi pembelajaran yang sebelumnya abstrak atau tidak dapat dilihat langsung itu menjadi konkret karena dapat dilihat, dirasakan, atau diraba.

b. Memberikan pengalaman nyata dan langsung karena siswa dapat berkomunikasi dan berinteraksi dengan lingkungan tempat belajarnya.

c. Mempelajari materi pembelajaran secara berulang-ulang. Misalnya belajar melalui rekaman kaset, tape recorder atau televisi.

d. Memungkinkan adanya persamaan pendapat dan persepsi yang benar terhadap suatu materi pembelajaran atau obyek. Misalnya ketika guru menyampaikan materi pembelajaran secara lisan melalui ceramah, maka ada kemungkinan terjadi perbedaan pendapat atau persepsi yang diterima oleh siswa.

Berdasarkan manfaat media pembelajaran yang telah dijelaskan di atas peneliti dapat menyimpulkan bahwa media pembelajaran sangat berperan penting dalam proses pembelajaran karena dengan adanya suatu media guru lebih mudah dan objektif dalam menerangkan suatu materi pembelajaran contohnya seperti menjelaskan rangka tubuh manusia pada mata pelajaran IPA.

Gagne dan Briggs sebagaimana dikutip Sumiati menyarankan suatu cara dalam langkah-langkah memilih media pembelajaran untuk pembelajaran. Langkah dalam memilih media pembelajaran menurut keduanya adalah: a. Merumuskan tujuan pembelajaran.

b. Mengklasifikasikan tujuan berdasarkan domain atau tipe belajar.

c. Memilih peristiwa-peristiwa pembelajaran yang akan berlangsung.

d. Menentukan tipe perangsang untuk tiap peristiwa.

e. Mendaftar media pembelajaran yang dapat digunakan pada setiap peristiwa dalam pembelajaran.

f. Mempertimbangkan (berdasarkan nilai kegunaan) media pembelajaran yang dipakai.

g. Menentukan media pembelajaran yang terpilih akan digunakan

h. Menulis rasional (penalaran) memilih media pembelajaran tersebut.

i. Menuliskan tata cara pemakaiannya pada setiap event (peristiwa)

j. Menuliskan script (naskah) pembicaraan dalam penggunaan media pembelajaran.

Berdasarkan pendapat para ahli tentang langkah-langkah pemilihan media pembelajaran di atas dapat disimpulkan bahwa langkah dalam memilih media pembelajaran yakni merumuskan tujuan pembelajaran, memilih peristiwaperistiwa pembelajaran yang akan dipelajari, menentukan media apa yang baik dan sesuai dengan isi materi yang akan disampaikan sehingga media yang akan digunakan dapat membuat peserta didik tertarik untuk memahami dan mempelajarinya.

\section{Syarat-syarat Pembuatan Media Pembelajaran}

Media pembelajaran yang dibuat (media by design) harus memenuhi syarat-syarat berikut ini:

a. Faktor edukatif, meliputi ketepatan atau kesesuaian media pembelajaran dengan tujuan atau kompetensi yang telah ditetapkan dan harus dicapai oleh peserta didik sesuai kurikulum yang berlaku. Selain itu, pembuatan media pembelajaran juga harus sesuai dengan tingkat kemampuan atau daya pikir peserta didik yang dapat 
mendorong aktivitas dan kreativitasnya sehingga membantu mencapai keberhasilan belajarnya.

b. Faktor teknik pembuatan, meliputi kebenaran atau tidak menyalahi konsep ilmu pengetahuan, bahan dan bentuknya kuat, tahan lama, tidak mudah berubah, sehingga dapat dikombinasikan dengan media pembelajaran atau alat lainnya.

c. Faktor keindahan, meliputi: bentuknya estetis, ukuran serasi dan tepat dengan kombinasi warna menarik, sehingga menarik perhatian dan minat peserta didik untuk menggunakannya.

Berdasarkan syarat-syarat pembuatan media pembelajaran di atas dapat disimpulkan bahwa syarat pembuatan media harus terdiri dari 3 faktor yakni faktor edukatif, faktor teknik pembuatan, dan faktor keindahan.

\section{Buletin Dalam Bentuk Buku Saku}

Buletin merupakan salah satu ragam media pembelajaran yaitu media cetak. Pengertian buletin seperti yang tercantum dalam Kamus Besar Bahasa Indonesia (1990) yaitu, "Media cetak berupa selebaran atau majalah berisi warta singkat atau pernyataan tertulis yang diterbitkan secara periodik oleh suatu organisasi atau lembaga untuk kelompok profesi tertentu. Pengertian buletin secara umum menurut Widjaya (2014) adalah: "Salah satu media komunikasi visual yang berbentuk kumpulan lembaran-lembaran atau bukubuku diusahakan secara teratur oleh suatu organisasi atau instansi. Dan dalam buletin dimuat pernyataan-pernyataan resmi dan singkat bagi publik.

Dari pengertian yang telah dikemukakan di atas dapat disimpulkan bahwa buletin merupakan suatu media cetak dalam bentuk majalah sederhana yang berisi tentang uraian singkat dan diterbitkan untuk kalangan sendiri ataupun suatu organisasi atau lembaga untuk mencapai tujuan tertentu.
Pengertian buku saku dalam Kamus Besar Bahasa Indonesia, buku saku adalah buku berukuran kecil yang dapat disimpan dalam saku dan mudah dibawa ke mana-mana. Buletin dalam bentuk buku yang dikembangkan dalam penelitian ini berukuran $10 \mathrm{~cm} \times 15 \mathrm{~cm}$ sehingga mudah dibawa.

Media pembelajaran berupa buletin dapat mendukung peserta didik untuk dapat belajar mandiri, yang dapat meningkatkan keahlian metakognisi (Herlianti, Linuwih, \& Dwijananti, 2015; Susilawati, Ristanto, \& Khoiri, 2015).

Sulistyani (2012) mengatakan beberapa hal yang harus diperhatikan dalam penyusunan pocket book, antara lain:

a. Konsistensi penggunaan simbol dan istilah pada pocket book,

b. Penulisan materi secara singkat dan jelas pada pocket book,

c. Penyusunan teks materi pada pocket book sedemikian rupa sehingga mudah dipahami,

d. Memberikan kotak atau label khusus pada rumus, penekanan materi dan contoh soal,

e. Memberikan warna dan desain yang menarik pada pocket book,

f. Ukuran font standar isi adalah 9-10 point, jenis font menyesuaikan isinya

g. Jumlah halamannya kelipatan dari 4 misalnya 12 halaman, 16 halaman, 20 halaman, 24 halaman, dan seterusnya. Hal ini dikarenakan untuk menghindari kelebihan atau kekurangan beberapa halaman kosong.

Buku teks merupakan salah satu jenis buku pendidikan. Menurut Muslich, "Buku teks adalah buku berisi uraian bahan tentang mata pelajaran atau bidang studi tertentu, yang disusun secara sistematis dan telah diseleksi berdasarkan tujuan tertentu, orientasi pembelajaran, dan perkembangan siswa"

Manfaat buku teks tidak hanya untuk siswa, tetapi guru pun terbantu dengan 
kehadiran buku teks. Selain digunakan oleh peserta didik, buku teks digunakan oleh guru pada waktu mengajar. Guru memiliki kebebasan dalam memilih, menyajikan, dan mengembangkan materi. Kelebihan buku teks sebagai media pembelajaran, antara lain: dapat berdampingan dengan media lain, dapat digunakan oleh semua kalangan, tidak memerlukan peralatan khusus dalam menggunakannya dan cara penggunaan mudah dan praktis.

Buku teks sebagai media pembelajaran juga memiliki kekurangan antara lain: tidak menarik dan monoton, membutuhkan waktu untuk memahami sebuah bacaan, tidak dapat digunakan dalam tempat gelap, membutuhkan konsep awal, memerlukan daya ingat yang tajam, membosankan, dan bersifat abstrak.

Dari pengertian tentang buku saku di atas dapat disimpulkan bahwa buku saku adalah suatu buku yang berukuran kecil yang berisi informasi yang dapat disimpan di saku sehingga mudah dibawa dan mudah untuk dibaca .

\section{Rancangan Buletin}

Adapun prosedur dalam merancang media buletin dalam bentuk buku saku untuk pembelajaran dapat dilakukan dengan langkah-langkah sebagai berikut:
a. Mengidentifikasi program.
b. Mengkaji literatur.
c. Membuat naskah.
d. Kegiatan produksi.

\section{METODE PENELITIAN}

Penelitian ini menggunakan metode penelitian dan pengembangan (Research and Development). Tujuan metode penelitian pengembangan ini digunakan untuk menghasilkan produk, serta mengetahui bagaimana tanggapan guru IPA serta peserta didik dan guru terhadap produk buletin IPA Terpadu pada materi bunyi yang dikembangkan untuk peserta didik SMP kelas VIII. $\begin{array}{rrr}\text { Prosedur } & \text { penelitian } \\ \text { pengembangan } & \text { (Research }\end{array}$ Development) buletin IPA Terpadu pada materi bunyi menggunakan model pengembangan yang dikemukakan Sugiyono. Produk yang dihasilkan berupa buletin yang dapat dimanfaatkan oleh guru dan peserta didik dalam meningkatkan kualitas pembelajaran IPA yang berimplikasi terhadap pencapaian tujuan pembelajaran.

Model Borg and Gall dalam Sugiyono ini meliputi: 1) Potensi dan Masalah, 2) Pengumpulan Data, 3) Desain Produk, 4) Validasi desain, 5) Perbaikan Desain, 6) Uji coba produk, 7) Revisi produk, 8) Uji coba pemakaian, 9) Revisi Produk, 10) Produksi massal.

Model ini memiliki langkah-langkah pengembangan yang sesuai dengan penelitian pengembangan pendidikan yaitu penelitian yang menghasilkan atau mengembangkan produk tertentu dengan melakukan beberapa uji ahli seperti uji materi, uji desain, uji coba produk kelompok kecil dan uji coba lapangan untuk menguji kemenarikan produk yang dikembangkan. Dalam penelitian pengembangan ini dibutuhkan sepuluh langkah pengembangan untuk menghasilkan produk akhir yang siap untuk diterapkan dalam lembaga pendidikan. Tetapi, dalam penelitian ini dibatasi langkah-langkah penelitian pengembangannya hanya sampai langkah ke 5 dikarenakan waktu yang kurang dan biaya yang terbatas. Produk akhir dari penelitian pengembangan ini berupa buletin IPA Terpadu pada materi bunyi.

Instrumen yang digunakan dalam penelitian ini adalah lembar observasi, lembar wawancara, lembar angket, lembar penilaian ahli materi dan lembar penilaian ahli media. Analisis data dilakukan untuk memperoleh kelayakan dari media pembelajaran yaitu berupa buletin IPA terpadu yang sudah direvisi. Hasil yang diperoleh digunakan sebagai bahan 
pertimbangan dalam memperbaiki buletin. Pengembangan ini menggunakan teknik analisa data yaitu dengan menganalisis deskriptif. Analisis deskriptif digunakan untuk menganalisis data hasil penilaian kelayakan adalah dengan perhitungan rata-rata. Sebagaimana data-data yang terkumpul dapat dikelompokkan menjadi dua yaitu: data kuantitatif yang berupa angka-angka dan data kualitatif yang berbentuk kata. Data kualitatif akan dianalisis secara logis dan bermakna, sedangkan data kuantitatif akan dianalisis dengan deskriptif perhitungan rata-rata. Hasil analisis deskriptif ini digunakan untuk menentukan tingkat kelayakan dari produk pengembangan berupa buletin IPA terpadu untuk peserta didik kelas VIII SMP Negeri 7 Bandar Lampung dan SMP Negeri 21 Bandar Lampung.

Kelayakan dari buletin IPA terpadu ini, diketahui melalui hasil analisis para ahli, yakni: 1) review oleh ahli materi bidang studi, 2) review oleh ahli desain, dan 3) review dari guru IPA. Dengan cara ini diharapkan dapat mempermudah memahami data untuk proses selanjutnya. Hasil analisis data digunakan sebagai dasar untuk merevisi produk buletin yang dikembangkan. Data mengenai pendapat atau tanggapan pada produk yang terkumpul melalui angket dianalisis dengan statistik deskriptif. Instrumen non tes berupa angket menggunakan skala Likert. Sudaryon dkk (2013) menyebutkan bahwa skala Likert digunakan untuk mengukur sikap, pendapat, persepsi seseorang atau sekelompok tentang kejadian atau gejala sosial. Dalam penelitian ini menggunakan skala 1 sampai 5 dengan skor tertinggi 5 dan skor terendah 1. Sehingga skor penilaian total dapat dicari dengan menggunakan rumus (Nurina, 2013).

Keterangan :

$$
P=\frac{\sum x}{\sum x i} \times 100 \%
$$

$\mathrm{P}=$ Persentase $\sum x=$ jumlah jawaban responden dalam 1 item

$\sum x i=$ jumlah nilai ideal dalam item

Sudijono (2012) mangatakan bahwa hasil dari skor penilaian menggunakan skala Likert tersebut kemudian dicari rataratanya menggunakan rumus.

$$
p=\frac{f}{N} \times 100 \%
$$

Keterangan :

$f=$ frekuensi yang akan dicari persentasenya

$N=$ jumlah frekuensi

$p=$ angka persentase

Tabel 1. Skala Interpretasi Kriteria

\begin{tabular}{cc}
\hline Interval & Kriteria \\
\hline $0 \%-20 \%$ & Sangat Kurang layak \\
$21 \%-40 \%$ & Kurang layak \\
$41 \%-60 \%$ & Cukup layak \\
$61 \%-80 \%$ & Layak \\
$81 \%-100 \%$ & Sangat layak \\
\hline
\end{tabular}

\section{HASIL DAN PEMBAHASAN}

\section{Potensi dan Masalah}

Hasil yang diperoleh dari potensi masalah yakni guru dalam kegiatan pembelajaran IPA belum pernah menggunakan media lain selain buku cetak dan Lembar Kerja Siswa. Hal ini disebabkan keterbatasan media pembelajaran sehingga pembelajaran tidak inovatif. Menurut Sadiman media pembelajaran adalah segala sesuatu yang dapat digunakan untuk menyalurkan pesan dari pengirim ke penerima pesan. Dalam hal ini adalah proses merangsang pikiran, perasaan, perhatian, dan minat serta perhatian peserta didik sehingga proses belajar dapat terjalin. Rahmani dalam penelitiannya, menyatakan bahwa pembelajaran fisika dengan menggunakan media membuat proses pembelajaran lebih menarik peserta didik dalam proses belajar.

\section{Mengumpulkan Informasi}

Informasi yang diperoleh bahwa sekolah tersebut belum melaksanakan pembelajaran IPA secara terpadu, dan 
belum tersedianya media belajar berupa buletin dalam bentuk buku saku yang dapat mengaitkan beberapa materi dalam satu pembelajaran.

Sesuai dengan amanat Kurikulum Tingkat Satuan Pendidikan (KTSP), bahwa model pembelajaran terpadu merupakan salah satu model implementasi kurikulum yang dianjurkan untuk diaplikasikan pada semua jenjang pendidikan, diaplikasikan terutama pada jenjang pendidikan dasar mulai dari Sekolah Dasar/Madrasah Ibtidaiah (SD/MI) maupun juga Sekolah Menengah Pertama (SMP/MTs) tetapi juga tidak menutup kemungkinan untuk dikembangkan pada tingkat pendidikan menengah, baik Pendidikan Menengah Umum (SMA/MA)maupun pendidikan Menengah Kejuruan (SMK/MAK).

Model pembelajaran ini pada hakikatnya merupakan suatu pendekatan pembelajaran yang memungkinkan peserta didik baik secara individual maupun kelompok aktif mencari, menggali, dan menemukan konsep serta prinsip secara holistis dan autentik. Pembelajaran terpadu, suatu konsep atau tema dibahas dari berbagai aspek bidang kajian. Misalnya dalam bidang kajian IPA tentang tema lingkungan dapat dibahas dari sudut makhluk hidup dan proses kehidupan (biologi), energi dan perubahannya (fisika), materi dan sifatnya (kimia).

\section{Desain Produk}

Setelah mengumpulkan informasi, selanjutnya mendesain produk awal buletin IPA Terpadu, dengan menyesuaikan standar kompetensi dan kompetensi dasar serta silabus berdasarkan kurikulum KTSP. Buletin IPA Terpadu dibuat dengan ukuran kertas A4; skala spaci 1,15; font 10pt; jenis huruf Comic Sans MS (Yulianti, Marfu'ah, \& Yulianto, 2015).

Menurut PP No.19/2005, buku teks yang baik memiliki empat komponen yaitu komponen kelayakan isi, kebahasaan, penyajian, dan kegrafikaan, beserta penjelasannya, sebagaimana diuraikan berikut. Sebuah buku teks pelajaran yang baik adalah buku yang:

a) Minimal mengacu pada sasaran yang akan dicapai peserta didik, dalam hal ini adalah standar kompetensi (SK dan KD). Dengan perkataan lain, sebuah buku teks pelajaran harus memperhatikan komponen kelayakan isi.

b) Berisi informasi, pesan, dan pengetahuan yang dituangkan dalam bentuk tertulis yang dapat dikomunikasikan kepada pembaca (khususnya guru dan peserta didik) secara logis, mudah diterima sesuai dengan tahapan perkembangan kognitif pembaca. Untuk itu, bahasa yang digunakan harus mengacu pada kaidah-kaidah bahasa Indonesia yang baik dan benar. Artinya, sebuah buku teks pelajaran harus memperhatikan komponen kebahasaannya.

c) Berisi konsep-konsep disajikan secara menarik, interaktif dan mampu mendorong terjadinya proses berpikir kritis, kreatif, inovatif dan kedalaman berpikir, serta metakognisi dan evaluasi diri. Dengan demikian sebuah buku teks pelajaran harus memperhatikan komponen penyajian, yang berisi teknik penyajian, pendukung penyajian materi, penyajiannya mendukung pembelajaran.

d) Secara fisik tersaji dalam wujud tampilan yang menarik dan menggambarkan ciri khas buku pelajaran, kemudahan untuk dibaca dan digunakan, serta kualitas fisik buku. Dengan perkataan lain buku teks pelajaran harus memenuhi syarat kegrafikaan.

Selanjutnya mendesain buletin IPA terpadu dengan mengadopsi tampilan dengan menggunakan majalah dan brosur sebagai acuan untuk mendesain buletin dalam bentuk buku saku, dengan menyesuaikan standar kompetensi dan kompetensi dasar serta silabus berdasarkan kurikulum KTSP. Dalam menyusun teks, gambar, halaman, jenis 
huruf, ukuran huruf, warna, dan sebagainya dalam desain majalah atau buletin, dan media cetak lain Buletin IPA Terpadu dibuat dengan ukuran kertas A4; skala spaci 1,15; font 10pt; jenis huruf Comic Sans MS.

\section{Validasi Produk}

Setelah pembuatan produk awal buletin IPA Terpadu pada materi bunyi selesai, langkah selanjutnya yaitu produk divalidasi oleh para ahli. Tim ahli terdiri dari 3 ahli materi dan 3 ahli desain. Instrumen validasi dalam angket penilaian ahli materi dan ahli desain menggunakan skala Likert. Validasi oleh ahli dilakukan dua kali, yaitu validasi penilaian produk awal dan validasi penilaian setelah produk direvisi. Adapun hasil validasi oleh ahli sebagai berikut:

\section{Validasi oleh ahli materi}

Penilaian ahli materi pada produk awal disajikan dalam diagram berikut ini:

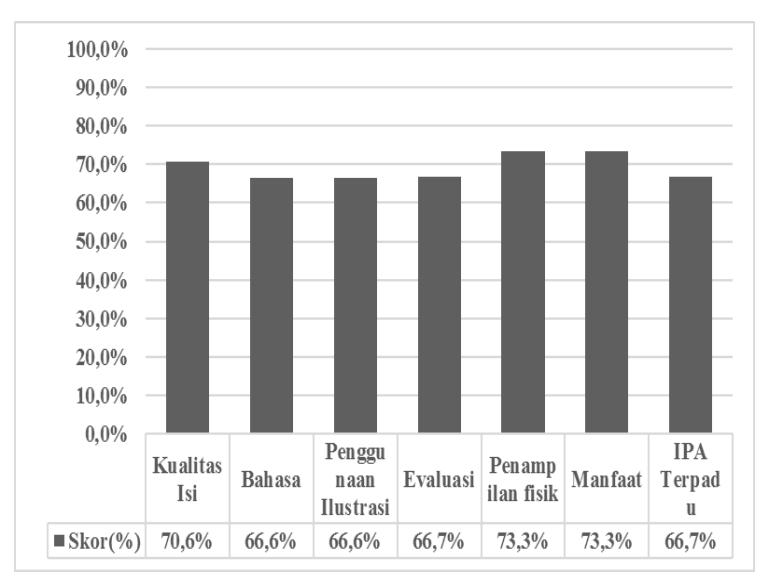

\section{Diagram 1. Validasi ahli materi pada produk awal}

Berdasarkan Diagram 1, hasil penilaian tertinggi pada produk awal terdapat pada aspek penampilan fisik dan manfaat yaitu $73,3 \%$ dikarenakan pada aspek penampilan fisik dan aspek manfaat indikator penilaian pada buletin memiliki daya tarik yang baik dan buletin dapat membantu peserta didik dengan belajar secara mandiri sedangkan pada Aspek kebahasaan, aspek penggunaan ilustrasi, aspek evaluasi, dan aspek IPA terpadu memperoleh penilaian yang paling terkecil pada produk awal yaitu $66,6 \%$ dikarenakan pada aspek kebahasaan, aspek penggunaan ilustrasi, aspek evaluasi, dan aspek IPA terpadu indikator penilaian pada buletin bahasa yang digunakan kurang populer, evaluasi pada buletin kurang jelas sehingga pada aspek evaluasi mendapatkan skor terendah, materi dalam buletin tentang bunyi yang dikemas dengan unit-unit kecil dalam aspek penggunaan ilustrasi mendapatkan skor terendah. Hasil penilaian tersebut adalah hasil penilaian untuk media pembelajaran berupa buletin dalam bentuk buku saku IPA terpadu sebelum direvisi.

Saran perbaikan yang diberikan oleh ahli materi adalah sebagai berikut:

\section{Tabel 2. Saran Perbaikan Ahli Materi}

\begin{tabular}{|c|c|c|c|}
\hline No & Aspek & $\begin{array}{c}\text { Saran } \\
\text { Perbaikan }\end{array}$ & $\begin{array}{c}\text { Hasil } \\
\text { Perbaikan }\end{array}$ \\
\hline 1 & $\begin{array}{l}\text { Aspek } \\
\text { penggunaan } \\
\text { Ilustrasi }\end{array}$ & $\begin{array}{l}\text { Indikator } \\
\text { disesuaikan } \\
\text { dengan } \\
\text { indikator } \\
\text { materi }\end{array}$ & $\begin{array}{l}\text { Indikator } \\
\text { sudah } \\
\text { disesuaikan } \\
\text { dengan } \\
\text { indikator } \\
\text { materi }\end{array}$ \\
\hline 2 & $\begin{array}{l}\text { Aspek } \\
\text { evaluasi }\end{array}$ & $\begin{array}{l}\text { Petunjuk } \\
\text { evaluasi } \\
\text { tidak jelas }\end{array}$ & $\begin{array}{l}\text { Petunjuk } \\
\text { evaluasi } \\
\text { sudah } \\
\text { diperjelas }\end{array}$ \\
\hline
\end{tabular}

Saran perbaikan yang diberikan oleh ahli materi pada produk awal yakni pada aspek penggunaan ilustrasi sarannya yaitu indikator disesuaikan dengan indikator materi, hasil perbaikan indikator sudah disesuaikan dengan indikator materi. Aspek evaluasi saran perbaikan petunjuk evaluasi tidak jelas, hasil perbaikan petunjuk evaluasi sudah diperjelas, sedangkan pada produk akhir sudah tidak ada saran perbaikan dan layak untuk digunakan tanpa revisi, sehingga buletin sudah bisa digunakan karena sudah melalui 2 kali validasi pada ahli materi. 
Hasil perbaikan materi produk awal sesuai dengan saran ahli materi disajikan pada diagram berikut:

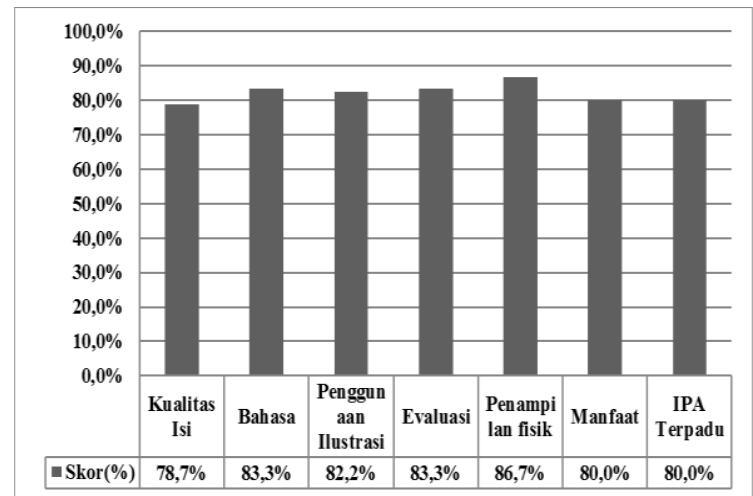

Diagram 2. Hasil Validasi materi produk awal sesuai saran perbaikan

Berdasarkan Diagram 2, hasil penilaian tertinggi pada produk awal terdapat pada aspek penampilan fisik yaitu $86,6 \%$ dikarenakan pada aspek penampilan fisik indikator penilaian buletin memiliki daya tarik yang baik, sedangkan pada Aspek kualitas isi mendapatkan penilaian terkecil pada produk akhir yaitu 78,6\% dikarenakan pada aspek kualitas isi indikator penilaian susunan materi kurang sistematis. Hasil penilaian tersebut adalah hasil penilaian untuk media pembelajaran berupa buletin dalam bentuk buku saku IPA terpadu sesudah direvisi

\section{Validasi oleh ahli desain}

Berikut ini adalah hasil validasi desain:

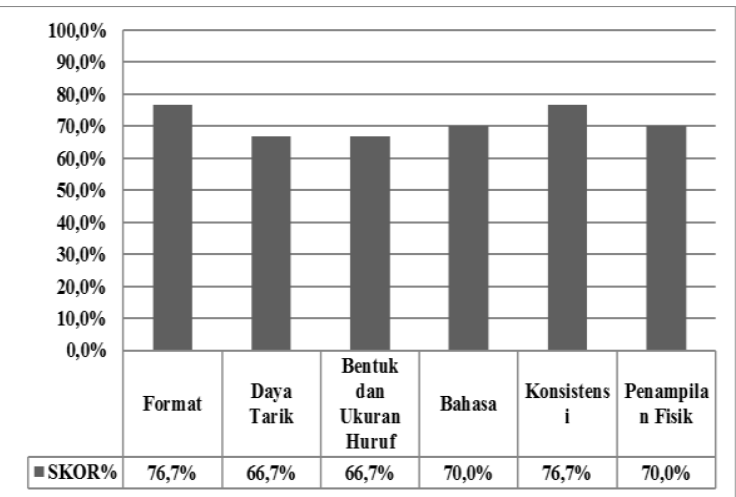

Diagram 3. Validasi ahli desain pada produk awal
Berdasarkan Diagram 3, hasil penilaian tertinggi pada produk awal terdapat pada aspek format dan konsistensi yaitu 76,6\% dikarenakan pada aspek format dan aspek konsistensi penilaian yang diperoleh dari indikator penilaian pada kesesuaian format kertas dengan tata letak, kesesuaian proporsi ilustrasi dengan ukuran kertas yang digunakan kekonsistenan jenis huruf dan kekonsistenan ukuran huruf sudah sesuai. Aspek daya tarik, aspek bentuk dan ukuran huruf memperoleh penilaian yang paling terkecil pada produk awal yaitu 66,6\% dikarenakan pada aspek daya tarik, aspek bentuk dan ukuran huruf penilaian yang diperoleh dari indikator penilaian pada penampilan sampul buletin kurang menarik, kelayakan isi buletin, kesesuaian penggunaan ukuran huruf masih belum sesuai dan ketepatan penggunaan variasi bentuk huruf. Hasil penilaian tersebut adalah hasil penilaian untuk media pembelajaran berupa buletin dalam bentuk buku saku IPA terpadu sebelum direvisi.

Saran perbaikan yang diberikan oleh ahli desain adalah sebagai berikut:

Tabel 3. Saran Perbaikan Ahli Desain

\begin{tabular}{clll}
\hline No & Aspek & $\begin{array}{c}\text { Saran } \\
\text { Perbaikan }\end{array}$ & $\begin{array}{c}\text { Hasil } \\
\text { Perbaikan }\end{array}$ \\
\hline 1. & $\begin{array}{l}\text { Aspek } \\
\text { daya } \\
\text { tarik }\end{array}$ & $\begin{array}{l}\text { Cover } \\
\text { disesuaikan }\end{array}$ & $\begin{array}{l}\text { Cover sudah } \\
\text { disesuaikan }\end{array}$ \\
2. & $\begin{array}{l}\text { Aspek } \\
\text { bentuk } \\
\text { dan } \\
\text { ukuran }\end{array}$ & $\begin{array}{l}\text { Ukuran font } \\
\text { tulisan } \\
\text { diperbesar } 9\end{array}$ & $\begin{array}{l}\text { Ukuran font } \\
\text { tulisan sudah } \\
\text { diperbesar 10 }\end{array}$ \\
huruf & $\begin{array}{l}\text { Aspek } \\
\text { bahasa }\end{array}$ & $\begin{array}{l}\text { Gunakan } \\
\text { bahasa yang } \\
\text { populer }\end{array}$ & $\begin{array}{l}\text { Penggunaan } \\
\text { bahasa sudah } \\
\text { menggunakan } \\
\text { bahasa yang } \\
\text { populer }\end{array}$ \\
\hline
\end{tabular}

Saran perbaikan yang diberikan oleh ahli desain pada produk awal yakni pada aspek daya tarik yaitu cover disesuaikan, hasil perbaikan cover sudah disesuaikan. Aspek bentuk dan ukuran huruf saran perbaikan ukuran font tulisan 
diperbesar 9 atau 10, hasil perbaikan ukuran font tulisan sudah diperbesar 10 . Aspek bahasa saran perbaikan gunakan bahasa yang populer, hasil perbaikan penggunaan bahasa sudah menggunakan bahasa yang populer, sedangkan pada produk akhir sudah tidak ada saran perbaikan dan layak untuk digunakan tanpa revisi, sehingga buletin sudah bisa digunakan karena sudah melalui 2 kali validasi pada ahli desain.

a. Media belajar IPA terpadu berupa buletin dalam bentuk buku saku baik digunakan sebagai media penunjang pembelajaran, sehingga peserta didik lebih mudah memahami materi pembelajaran dan wawasan peserta didik semakin luas.

b. Animasi gambar petunjuk membuat peserta didik lebih tertarik untuk membacanya.

c. Materi dalam buletin sudah memenuhi syarat dalam standar kompetensi, kompetensi dasar dan indikator yang sesuai dengan kurikulum yang berlaku saat ini.

d. Kemenarikan sampul depan buletin IPA terpadu menimbulkan minat peserta didik untuk membacanya.

Hasil perbaikan desain produk awal sesuai dengan saran ahli disajikan pada diagram berikut:

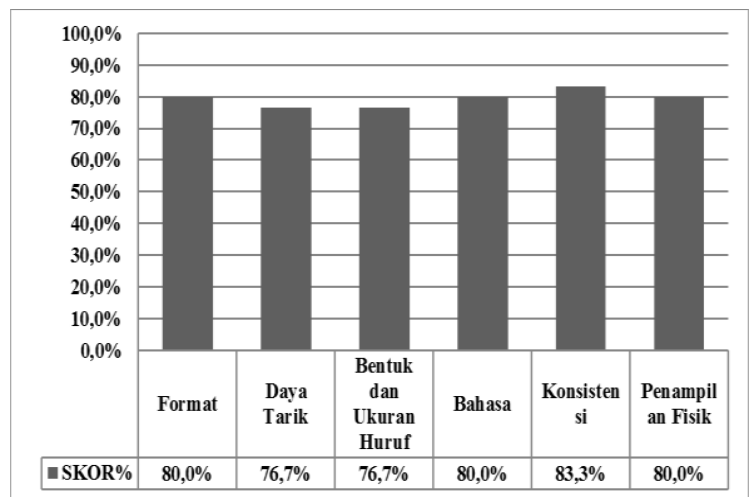

Diagram 4. Hasil Validasi desain produk awal sesuai saran perbaikan

Berdasarkan aspek Diagram 4, hasil penilaian tertinggi pada produk akhir terdapat pada aspek konsistensi yaitu
83,3\% dikarenakan pada aspek konsistensi penilaian yang diperoleh dari indikator penilaian pada kekonsistenan ukuran, kekonsistenan jenis huruf sudah sesuai sedangkan pada aspek daya tarik dan aspek bentuk dan ukuran huruf memperoleh penilaian yang paling terkecil pada produk akhir yaitu 76,6\% dikarenakan pada aspek daya tarik, aspek bentuk dan ukuran huruf penilaian yang diperoleh dari indikator penilaian pada penampilan sampul buletin, kelayakan isi buletin , kesesuaian penggunaan ukuran huruf dan ketepatan penggunaan variasi bentuk huruf belum sesuai. Hasil penilaian tersebut adalah hasil penilaian untuk media pembelajaran berupa buletin dalam bentuk buku saku IPA terpadu sesudah direvisi.

\section{Penilaian Guru}

Penilaian oleh guru IPA SMP pada produk buletin disajikan dalam diagram berikut ini:

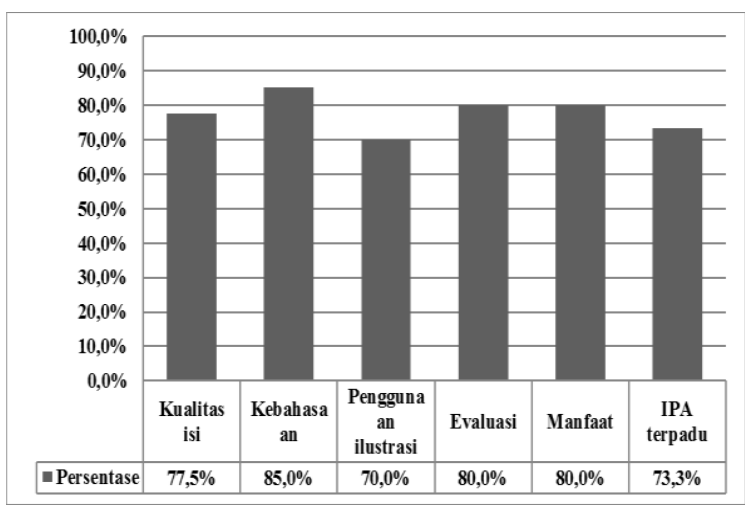

Diagram 5. Penilaian Guru

Berdasarkan Diagram 5, hasil penilaian tertinggi pada aspek kebahasaan yaitu $85 \%$, dikarenakan pada aspek kebahasaan indikator penilaiannya kalimat yang digunakan sesuai dengan kaidah bahasa yang baik dan benar karena dalam buletin bahasa yang digunakan harus baik sehingga mudah dipahami oleh peserta didik sedangkan pada aspek penggunaan ilustrasi mendapatkan skor terendah yaitu $70 \%$ dikarenakan pada aspek ilustrasi indikator penilaiannya 
pada ketepatan jenis ilustrasi dengan materi kurang mendukung., buletin dikategorikan layak digunakan sehingga media buletin dapat digunakan oleh guru untuk menyampaikan materi bunyi, juga dapat mempermudah guru maupun peserta didik untuk mempelajari materi bunyi.

\section{Respons Peserta Didik}

Berikut ini adalah hasil respons peserta didik terhadap produk yang dikembangkan:

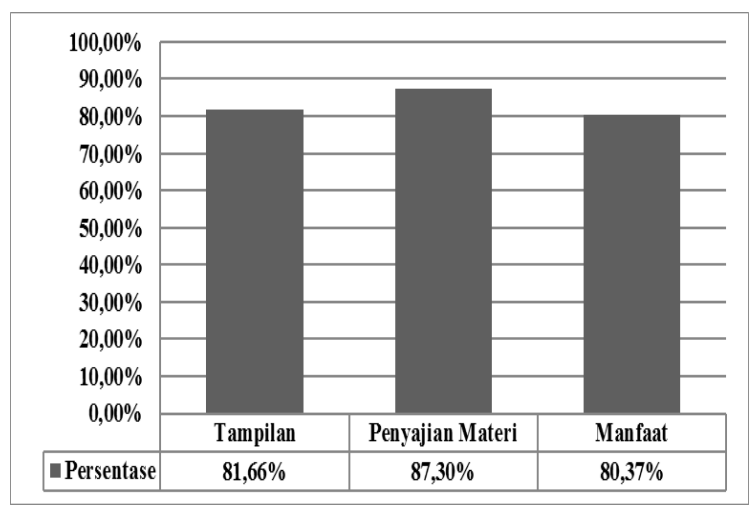

Diagram 6. Hasil Respons Peserta Didik

Berdasarkan Diagram 6, hasil penilaian tertinggi pada aspek penyajian materi yaitu $87,3 \%$, dikarenakan pada aspek penyajian materi indikator penilaian yaitu berupa penyajian materi, kemudahan memahami materi, ketepatan sistematika penyajian materi, kejelasan kalimat, kejelasan simbol dan lambang, kejelasan istilah dan kesesuaian contoh dengan materi yang sudah sesuai dengan indikator penilaian tiap aspek sedangkan penilaian terendah pada aspek manfaat yaitu 80,3\%, dikarenakan pada aspek manfaat indikator yang dinilai kemudahan belajar, ketertarikan menggunakan media buletin untuk pembelajaran IPA dan peningkatan motivasi belajar .

Hasil produk buletin yang telah direvisi dan menjadi produk akhir yang siap untuk digunakan disajikan pada Lampiran 2.

\section{SIMPULAN DAN SARAN Simpulan}

Berdasarkan pembahasan dan hasil pengembangan dalam proses yang dikembangkan dalam penelitian pengembangan (research and development). Maka dapat disimpulkan bahwa dalam pengembangan media pembelajaran IPA Terpadu layak untuk dijadikan sebagai media pembelajaran IPA. Simpulan yang dapat diambil dari penelitian pengembangan ini adalah sebagai berikut:

1. Pengembangan media pembelajaran berupa buletin IPA terpadu dalam bentuk buku saku, dikembangkan dengan menggunakan metode Research and Development model Sugiyono yang telah dimodifikasi yang dikembangkan melalui proses potensi masalah, mengumpulkan informasi, mendesain produk, validasi ahli materi, validasi ahli desain, penilaian guru, respon peserta didik, revisi produk dan produk cetak. Buletin IPA terpadu berisi berstandar kompetensi, kompetensi dasar, indikator, materi belajar.

2. Respon peserta didik terhadap kelayakan buletin dalam bentuk buku saku IPA terpadu yang dihasilkan teruji layak digunakan sebagai media pembelajaran berdasarkan hasil respons peserta didik yang dilakukan terhadap peserta didik kelas VIII SMP Negeri 7 Bandar Lampung dan SMP Negeri 21 Bandar Lampung yang berjumlah 40 orang peserta didik.

\section{Saran}

Saran penelitian pengembangan ini adalah:

1. Hendaknya dalam membelajarkan IPA Terpadu tidak hanya menggunakan satu sumber belajar tetapi bisa menggunakan buletin dalam bentuk buku saku IPA terpadu yang telah dikembangkan oleh penulis agar dapat 
membantu peserta didik untuk lebih memahami konsep pelajaran IPA.

2. Sebaiknya guru lebih kreatif dalam melakukan modifikasi bahan ajar yang telah tersedia agar pembelajaran tidak monoton.

3. Harapannya untuk peneliti-peneliti selanjutnya dapat mengembangkan buletin dalam bentuk buku saku ini dengan desain yang berbeda dari yang sudah ada.

\section{DAFTAR PUSTAKA}

Herlianti, P. S., Linuwih, S., \& Dwijananti, P. (2015). Independent Learning Strategy Of Natural Science With "One Day One Diary For Science" Program. Jurnal Pendidikan Fisika Indonesia, 11(2), 148-155. doi:10.15294/jpfi .v11i2.4255

Nurina, dkk. 2013. Pengembangan Lembar Kerja Siswa (LKS) dengan Model Siklus Belajar 5E Berbasis Konstruktivistik pada Materi Sistem Sirkulasi Manusia untuk Kelas XI SMA. (Unpublished). Universitas Negeri Malang, Malang.

Setyono, Yulian Adi dkk. 2013. Pengembangan Media Pembelajaran Fisika Berupa Buletin dalam Bentuk Buku Saku untuk Pembelajaran Fisika Kelas VIII Materi Gaya Ditinjau dari Minat Baca Siswa. (Unpublished). Fakultas Keguruan dan Ilmu Pendidikan UNS, Surakarta.

Sudaryono, dkk. 2013. Pengembangan Instrumen Penelitian Pendidikan. Yogyakarta: Graha Ilmu.

Sudijono, Anas. 2012. Statistik Pendidikan. Jakarta: Rajawali Pers.

Sugiyono. 2013. Metode Penelitian Kuantitatif dan Kualitatif dan $R \& D$. Bandung: Alfabeta.

Sulistyani, Nurul Hidayati Dyah. 2012. Perbedaan Hasil Belajar Siswa antara Menggunakan Media Pocket Book dan tanpa Pocket Book pada Materi Kinematika Gerak Melingkar Kelas X. (Unpublished). Fakultas
Keguruan dan Ilmu Pendidikan UNS, Surakarta.

Sumiati, Asra. 2008. Metode Pembelajaran. Bandung: Wacana Prima.

Susilawati, Ristanto, S., \& Khoiri, N. (2015). Pembelajaran Real Laboratory Dan Tugas Mandiri Fisika Pada Siswa Smk Sesuai Dengan Keterampilan Abad 21. Jurnal Pendidikan Fisika Indonesia, 11(1), 73-83. doi:10.15294/jpfi.v11i1.4005

Tim penyusun, 1990. Kamus Besar Bahasa Indonesia. Jakarta: Balai pustaka.

Trianto. 2012. Model Pembelajaran Terpadu. Jakarta: Bumi Aksara.

Widjaja, Pengertian Buletin, 2014. (Online)http://elib.unikom.ac.id/downloa dphp?i7636.html, (diakses 1 Februari 2014)

Yulianti, D., Marfu'ah, S., \& Yulianto, A. (2015). Development Of Physics Student Work Sheet (Sws) To Build Science Process Skill Valued Conservation. Jurnal Pendidikan Fisika Indonesia, 11(2), 126-133. doi:10.15294/jpfi .v11i2.4246 